Pesq. Vet. Bras. 30(10):897-902, outubro 2010

\title{
Ultrastructural characterization of bovine umbilical cord blood cells ${ }^{1}$
}

\author{
Gustavo C. Rodrigues², Lílian J. Oliveira², Janaína M. Monteiro², Ana \\ R. de Lima ${ }^{2}$, Patricia O. Gonçalez²,Francisco J. Hernandez-Blazquez², \\ Rudolf Leiser ${ }^{3}$ and José R. Kfoury $\mathrm{Jr}^{2}$
}

\begin{abstract}
Rodrigues G.C., Oliveira L.J., Monteiro J.M., Lima A.R., Gonçalez P.O., Hernandez-Blazquez F.J., Leiser R. \& Kfoury Jr J.R. 2010. Ultrastructural characterization of bovine umbilical cord blood cells. Pesquisa Veterinária Brasileira 30(10):897-902. Departamento de Cirurgia, Faculdade de Medicina Veterinária e Zootecnia da Universidade de São Paulo, Av. Prof. Dr. Orlando de Marques Paiva 87, Cidade Universitária, São Paulo, SP, 05508-270, Brazil. E-mail: irobertok@usp.br

The umbilical cord blood (UCB) is an important source of pluripotent stem cells, which motivated researches on ontogeny and transplantation. The morphological characterization of umbilical cord cells is the first step to establish subsequent experiments on these areas. Although some information on humans can be found, no data on UCB is available for bovines. Therefore, this work is the first attempt to conduct an ultrastructural characterization of bovine umbilical cord blood. Blood was collected from the umbilical cord of twenty fetuses by punction of the umbilical vein. Samples were processed for whole leucocytes observation by centrifugation and the buffy coat was collected. Cells were washed and pelleted and prepared according to the standard protocol of the transmission electron microscopy. The presence of cells with morphologic characteristics compatible with the precursors from the erythrocytic, neutrophilic, eosinophilic, basophilic, and lymphocytic lineages was observed. Atypical cells with peculiar morphological features, strongly similar to apoptotic cells, were seen. Bovine neutrophils with three types of cytoplasmic granules were also found in the blood. The ultrastructural characteristics of observed bovine UCB cells where similar to those found in other species, suggesting that bovines could possibly constitute an experimental model for approaches on UCB cells research.
\end{abstract}

INDEX TERMS: Umbilical cord blood cells, haematopoietic progenitor cells, bovine, ultrastructure.

RESUMO.- [Caracterização ultra-estrutural das células sanguíneas do cordão umbilical bovino.] O sangue de cordão umbilical (SCU) é uma importante fonte de células progenitoras pluripotentes, que motiva pesquisas em ontogenia e transplantes. A caracterização morfológica das células de cordão umbilical é o primeiro passo para se estabelecer experimentos subsequentes nessas áreas. Embora algumas informações sobre SCU em humanos

\footnotetext{
${ }^{1}$ Received on June 15, 2010.

Accepted for publication on August 26, 2010.

2 Departamento de Cirurgia, Faculdade de Medicina Veterinária e Zootecnia, Universidade de São Paulo (USP), Av. Prof. Dr. Orlando de Marques Paiva 87, Cidade Universitária, São Paulo, SP 05508-270, Brazil.

${ }^{*}$ Corresponding author: jrobertok@usp.br

${ }^{3}$ Institut für Veterinär Anatomie, Histologie und Embryologie der JustusLiebig-Universität Giessen, Frankfurter Str. 98, Giessen, Germany.
}

possam ser encontradas, não existe nenhuma informação disponível sobre elas em bovinos. Portanto, este trabalho é a primeira tentativa de se conduzir uma caracterização ultra-estrutural do sangue de cordão umbilical bovino. 0 sangue foi coletado do cordão umbilical de 20 fetos por punção da veia umbilical. As amostras foram processadas para observação dos leucócitos totais por centrifugação pela coleta do botão leucocitário. As células foram lavadas, peletizadas e preparadas de acordo com protocolo padrão para microscopia eletrônica de transmissão. A presença de células com características morfológicas compatíveis com precursores das linhagens eritrocítica, neutrofílica, eosinofílica, basofílica e linfocítica foram observadas. Células atípicas com características morfológicas peculiares muito semelhantes a células em apoptose foram observadas. No sangue do cordão umbilical também foi encontrado neutrófilos bovinos apresentando três 
tipos de grânulos citoplasmáticos. As características ultraestruturais do SCU bovino foram semelhantes às encontradas em outras espécies, sugerindo que esta espécie possa servir como modelo experimental para abordagens em pesquisas sobre sangue de cordão umbilical.

TERMOS DE INDEXAÇÃO: Células do cordão umbilical, células progenitoras hematopoiéticas, bovino, ultra-estrutura.

\section{INTRODUCTION}

Hematopoietic stem cells from bone marrow and peripheral blood have been used to treat several disorders (Deliliers et al. 2001, Wynter \& Testa 2001). Human umbilical cord blood has recently been considered as a rich source of such cells (Deliliers et al. 2001, Wynter \& Testa 2001), which have a high proliferative potential, are capable of expanding upon cytokine stimulation and can engraft myeloablated recipients. For these reasons, cord blood has been increasingly used for allogenic transplantation (Deliliers et al. 2001). The hematopoetic stem cells from bone marrow, peripheral blood and cord blood have been widely characterized both functionally and molecularly, but there are few ultrastructural studies on cord blood cells (Deliliers et al. 2001).

Umbilical cord blood (UCB) cells of domestic animals have been studied in pre-clinic approaches (Ladgies et al. 1990, Niemeyer et al. 2001). Nevertheless their ultrastructural characteristics have not been considered in most species.

The aim of this study was to characterize the ultrastructure of different cells present in the umbilical cord blood of bovine with particular reference to the hematopoetic stem cells.

\section{MATERIALS AND METHODS}

Blood was collected at local abattoir from umbilical cord of twenty bovine fetuses (second and third trimester of pregnancy) by direct punction of the umbilical vein using syringes with citrate phosphate dextrose adenine (CPDA) as anticoagulant. Samples were processed by centrifugation for whole leucocytes observation (1400x $\left.\mathrm{g}, 20^{\circ} \mathrm{C}, 15 \mathrm{~min}\right)$ and the buffy coat collected. Cells were washed three times $\left(800 \mathrm{x} \mathrm{g}, 20^{\circ} \mathrm{C}, 5 \mathrm{~min}\right)$, pelleted and prepared for transmission electron microscopy as follows: cells were fixed in $2.5 \%$ glutaraldehyde in $0.1 \mathrm{M}$ phosphate buffer for $60 \mathrm{~min}$ on ice. After that, the samples were washed five times with $7 \%$ sucrose and postfixed with $1 \% \mathrm{OsO}_{4}$ in phosphate buffer for $90 \mathrm{~min}$ on ice. The cells then were dehydrated in an ascending series of ethanol concentrations and embedded in Spurr resin (Electron Microscopy Science, PA, USA). Ultrathin sections were cut and stained with $2 \%$ uranyl acetate and $0.2 \%$ lead citrate. The cells were observed under a JEM-1010 transmission electron microscope (Jeol Ltd, Tokyo, Japan).

\section{RESULTS}

\section{Blast cells}

This cell type is the most frequent among the cord blood cells and its diameter ranging from 8.0 to $10.0 \mu \mathrm{m}$. It is characterized by a round nucleus (5.0-7.0 $\mu \mathrm{m}$ in diameter) with defined membrane, sparse chromatin condensation, enlarged and conspicuous nucleoli. The cytoplasm is electron- light, abundant with poorly developed organelles and large mitochondria and ribosome dispersed along it. (Fig.1A).

\section{Granulocytes}

Umbilical cord blood granulocytes show an average diameter from around 5 to $7 \mu \mathrm{m}$ and different stages of maturity as described below:

\section{Neutrophils}

These cells present a segmented nucleus with two or three lobes with dense chromatin and an average diameter of $3.5 \mu \mathrm{m}$. The electron-dense cytoplasm contains two or three different types of granules (Gr.1, Gr.2, Gr.3), distinguishable by their electrondensity and shape. Gr.1 display a round shape and weak electron-density, Gr.2 was also round and more electron-dense than Gr.1. Gr.3 show a pleomorphic shape and high electron-density. In the cytoplasm few mitochondria, disperse ribosomes and occasional vacuolated structures are also identified.

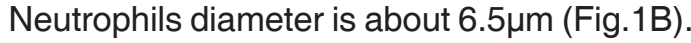

\section{Band cells}

These cells are undifferentiated and present a segmented nucleus, with sparse chromatin and evident nucleoli. The cytoplasm contains round to elongated shaped granules with varied diameters and electron-density. A significant quantity of mitochondria can be observed as well as vacuolated structures among the granules. The cell diameter is from 5 to $6.5 \mu \mathrm{m}$ (Fig.1C).

\section{Eosinophils}

Cells consistent with eosinophilic characteristics present a diameter around $7 \mu \mathrm{m}$ and show a segmented nucleus with condensed chromatin. A large amount of granules of varying morphology and electron-density with a crystalloid structure in their interior is observed in the cytoplasm, as well as scattered ribosome and few mitochondria (Fig.1D).

\section{Basophils}

Basophil precursor cells also are found in the bovine umbilical cord blood. These cells present a diameter of about $6.4 \mu \mathrm{m}$ and show a round nucleus with sparse chromatin and eccentric nucleoli. The nuclear/cytoplasmic ratio is low, and in the electron-light cytoplasm a great number of high electron-dense granules and moderate presence of vacuoles can be observed (Fig.2A).

\section{Lymphocytes}

Most of the lymphocytes of cord venous blood show diameters of 5 to $6 \mu \mathrm{m}$. They are mature with characteristics like round shaped nucleus with dense chromatin along the margin, cytoplasm with some indistinct mitochondria and numerous dispersed free ribosomes and Golgi complexes, represented by smooth, small round vesicles or elongated tubules and located near the nuclear indentations. These cells display a high nuclear/cytoplasmic ratio (Fig.2B).

Some lymphocytes enclosed a peculiar nucleus of cloverleaf like appearance and predominantly electron- 
Fig.1. (A) Blast of bovine cord blood. Round nucleus (N), sparse chromatin condensation, enlarged and conspicuous nucleolus and an electronlight wide cytoplasm with few organelles, like large mitochondria (white dotted arrow) and scarce ribosomes (Bar: 1 $\mu \mathrm{m})$. (B) Neutrophil from cord blood with segmented nucleus with dense chromatin and three different types of granules in the cytoplasm (Gr.1, Gr.2, Gr.3). The Gr.1 (arrowheads) show round shape and weak electrondensity, Gr.2 (white arrows) round shape and more intense electrondensity than Gr.1, and Gr.3 (thick black arrows) display pleomorphic shape and a high electrondensity. Few mitochondria (white dotted arrow), dispersed ribosomes, and occasional vesiculated structures can be observed (Bar: 500nm). (C) Bovine UCB Band cell: featuring a segmented nucleus with sparse chromatin and evident nucleoli, and a cytoplasm with round to elongated shaped granules with varied diameters and electrondensity (arrows). Several mitochondria also can be observed as well as clear vesiculated structures (arrowheads) among the granules. Granular endoplasmic reticulum (dotted arrow) and a fat droplet (FD) are also present (Bar: 500nm). (D) Cord blood eosinophil displaying seg-mented nucleus with condensed chromatin. In the cytoplasm, a large amount of granules (arrows) of varying morphology and electron-density with crystalloid structure in their interior, as well as scattered ribosomes and few mitochondria can be identified (Bar: 500nm).

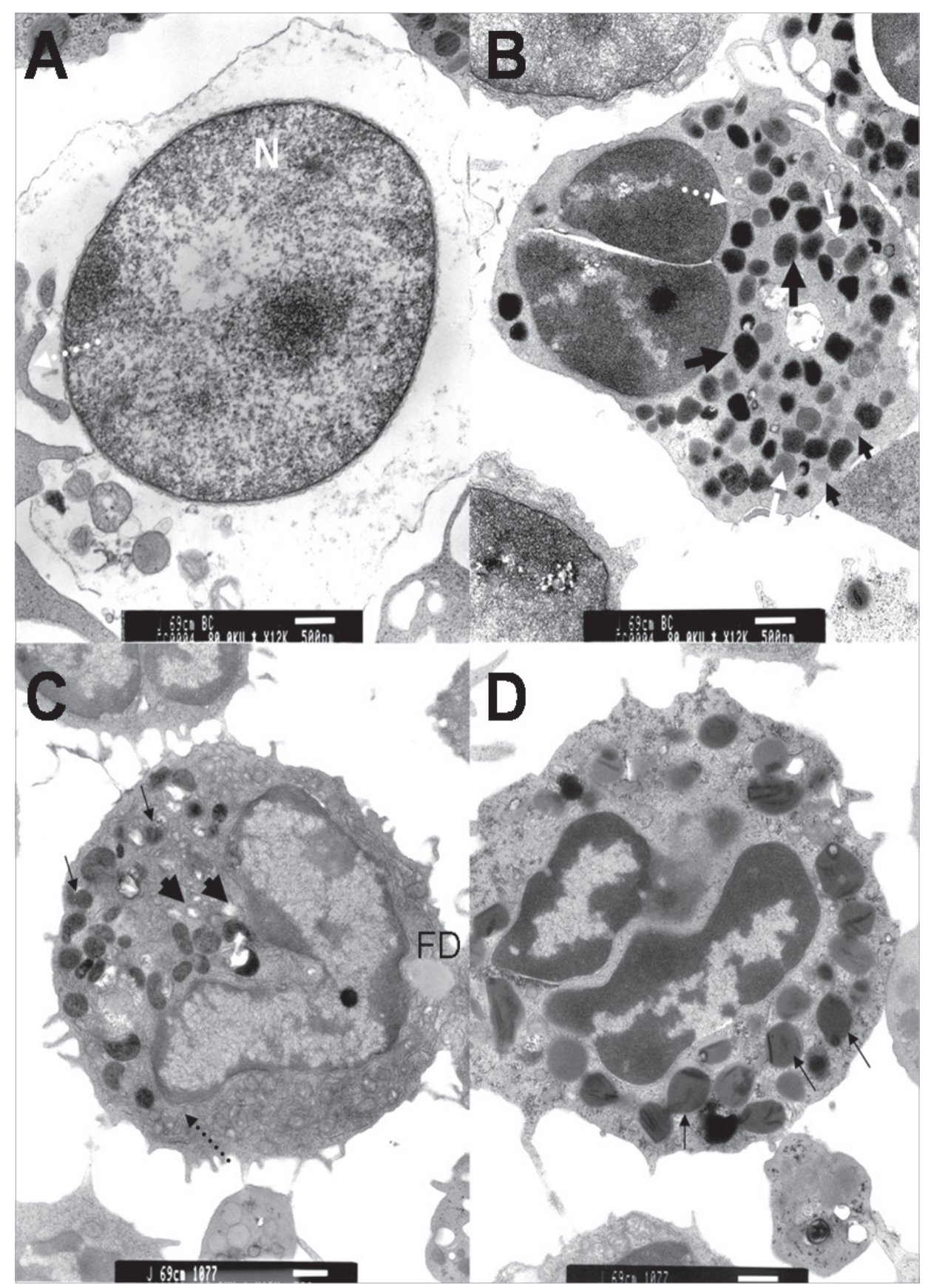

dense with some defined areas of sparse chromatin (Fig.2C). The cytoplasm is electron-dense containing scattered free ribosomes and a moderate number of mitochondria. Parts of these mitochondria seem to be undergoing a desegregation process, evidenced by interior vacuolization and dissociation of lamellae.

\section{Platelets}

Thrombocytes presenting an irregular round to spindlelike shape can be observed. Their cytoplasm is electrondense, with prominent granularity (dense granules) and some vacuolar areas of varied configuration and contents (Fig.2D). The cell diameters are about $4.5 \times 1.8 \mu \mathrm{m}$.

\section{Erythrocytes}

Erythrocyte precursors can be observed. They display an irregular round to elliptical shape and the mean size of them varies from 3.0 to $5.0 \mu \mathrm{m}$ in diameter. They are characterized by a segmented nucleus with condensed chromatin and an extensive electrondense cytoplasm with few ribosomes (Fig.3A).

\section{Other cells}

Cells observed in the umbilical cord blood which do not pertain to distinct cell types or lineages as presented above display features like great volume variability, shrinking ruffled and blebbed plasma membrane, extremely 


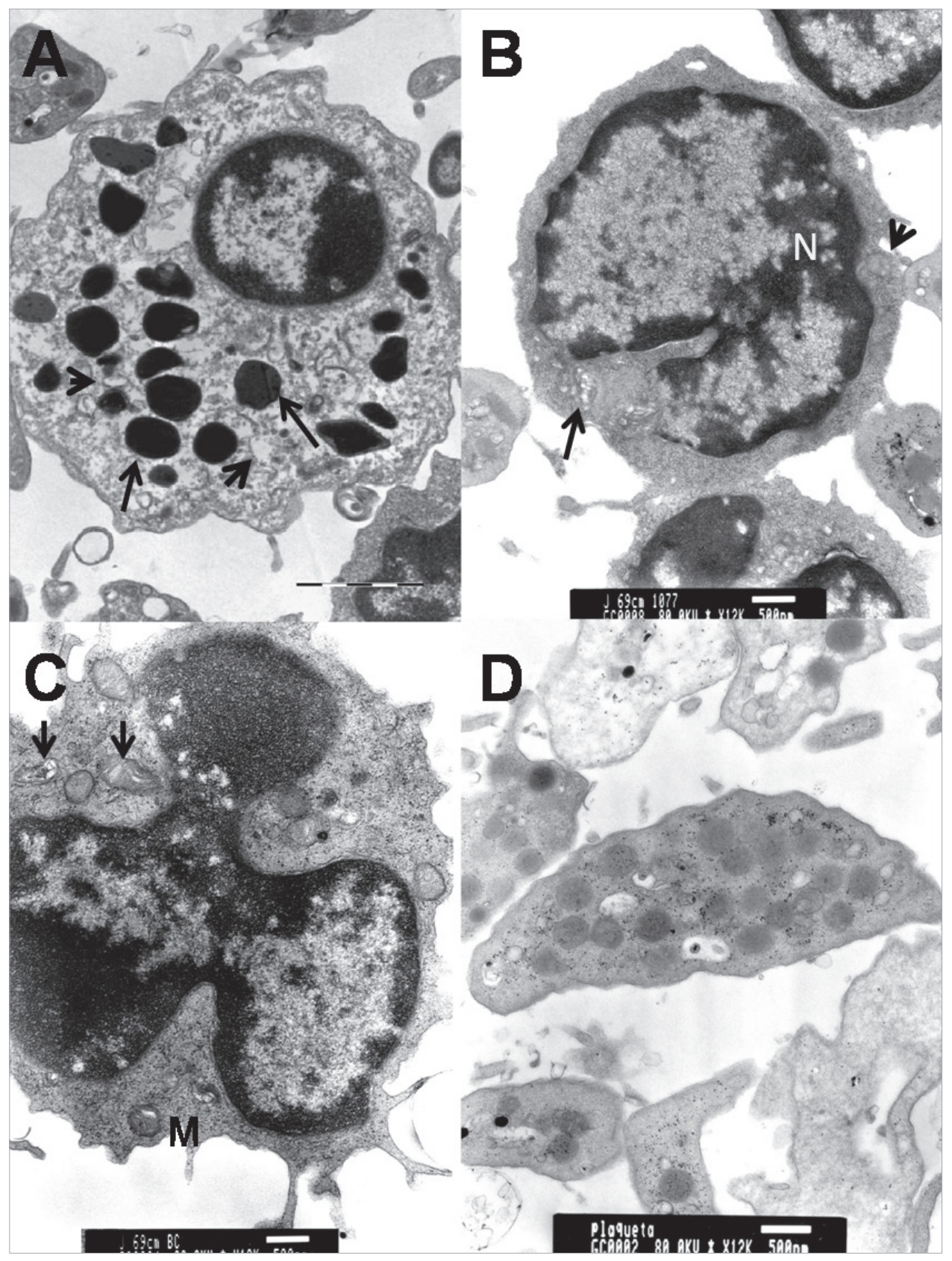

Fig.2. (A) Bovine UCB Basophil displaying round nucleus with sparse chromatin and eccentric nucleus. In the electron-light cytoplasm, note the great number of high electrondense granules (arrows) and the moderate presence of vacuoles - arrowheads (Bar: $2 \mu \mathrm{m}$ ). (B) Lymphocyte of bovine cord blood. The outlined nucleus $(\mathrm{N})$ appears irregular and contains areas of chromatin condensation mainly along the nuclear membrane. The cytoplasm contains numerous dispersed free ribosomes (dense particles) and some indistinct mitochondria (arrowhead). A Golgi complex (arrow), represented by smooth, small round vesicles or elongated tubules can be observed near a nuclear indentation. This cell displays a high nuclear/cytoplasmic ratio (Bar: 500nm). (C) Apoptotic UCB lymphocyte showing a peculiar cloverleaf-like shaped nucleus, predominantly electrondense with some defined areas of sparse chromatin. The cytoplasm is electrondense with scattered free ribosomes and a moderate number of mitochondria (M), which in part seem to be undergoing a desegre-gation process evidenced by interior vacuolization and lamellae dissociation (arrow) (Bar: 500nm). (D) Bovine UCB platelet showing an electrondense cytoplasm with prominent granules and some vacuolar areas of varied configuration contents (Bar: 500nm). condensed cytoplasm with normally appearing organelles as well as nuclear vesicles and chromatin fragments dispersed in the cytoplasm (Fig.3B).

\section{DISCUSSION}

Bovine umbilical cord blood cells examined under electron microscope showed a wide range of morphologic characteristics consistent to those found in precursors from blast cells, erythrocytic, neutrophilic, eosinophilic, basophilic, monocytic and lymphocytic lineages. Mature cells were also observed, as well as cells showing morphological features of apoptotic processes. The presence of a large number of immature cells was evident as reported by other authors in human umbilical cord blood (Mikami et al. 2002), suggesting that haematopoiesis is normally present in the cord blood besides the fetus (Carbonell et al. 1982, Alsami \& Filippich 1999).

Bovine UCB blast cells ultrastructure was very similar to those reported for other species (Capone et al. 1964, Athens 1993a, Jain 1993a, Mikami et al. 2002) and to those from bone marrow, nevertheless it does not necessarily mean they are homologous, since no specific markers were used.

Granulocytes found in this study including band cells, basophils, eosinophils and neutrophils showed ultrastructural characteristics similar to those described by some authors in humans (Capone et al. 1964, Athens 1993a,b, Jain 1993b). The presence of granules of different aspects 


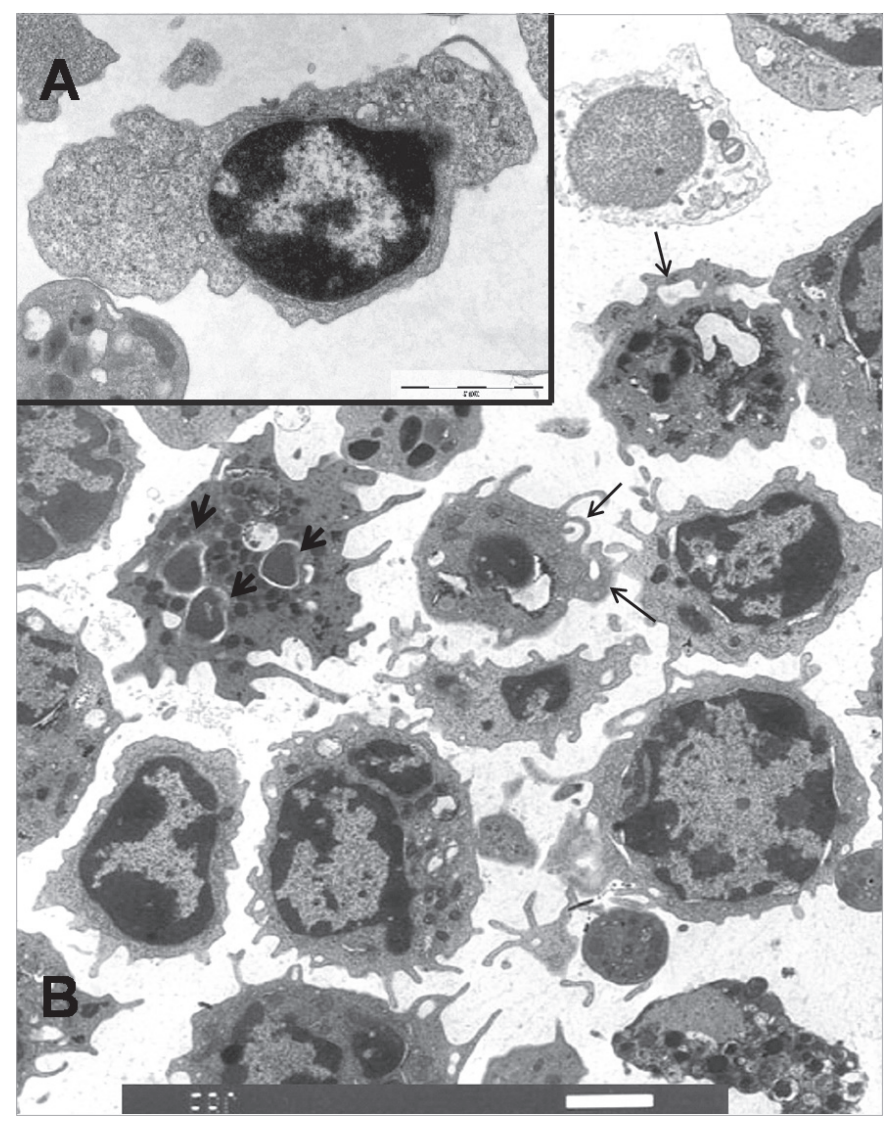

Fig.3. (A) Erythrocyte precursor of bovine UCB displaying an irregular round to elliptical shape. Besides the irregularly formed nucleus with condensed chromatin, observe the extensive and condensed cytoplasm with few dispersed ribosomes. Bar: 2mm. (B) Apoptotic cells of bovine cord blood with significant shrinking of volume, ruffled and blebbed plasma membrane (arrows), extremely condensed cytoplasm as well as nuclear vesicles and dispersed chromatin fragments (arrow head). Bar: $2 \mathrm{~mm}$.

was used as pattern for cells from the granulocytic lineage in different maturation stages, where primary granules are predominant in an early stage being surpassed by secondary granules in the end of the maturation process (Capone et al. 1964, Athens 1993a).

Band cells that represent the last stage of granulocytic maturation before nucleus segmentation were identified and their morphology was comparable to those described for human and animal bone marrow by Athens (1993a) and Jain (1993b).

Eosinophil precursors in the bovine UCB displayed granules which contain dense crystalloid structure as seen in mature human eosinophils (Mikami et al. 2001).

Bovine UCB neutrophils showed three different types of granules in the cytoplasm similar to those described by Gennaro (1983) and Baggiolini (1985) in the ruminant peripheral blood. The bovine additional granule (Gr.2) is larger and considerably more numerous than the two other types, azurophil (Gr.3) and specific granules (Gr.1).

The presence of erythrocytes or their precursors was expected since they are a common feature in the UCB and progressively increases during fetal development (Jain 1993a, Alsami \& Filippich 1999).

A relevant point in this work was that in the UCB there was a high concentration of cells presenting morphological features that are strongly similar to apoptotic cells. They have been reported by several authors in humans (Cohen 1993, Peters et al. 1998) and their characteristics include generalized cell shrinkage and increased cell density, the chromatin becomes pycnotic and is compacted into a halfmoon shape attached to the nuclear membrane. Karyorrhexis is evident and the cell appears to bud, and often contains pycnotic nuclear fragments (Duvall \& Wyllie 1986, Ihara et al. 1988).

Cellular death is part of organized tissue reactions in embryogenesis, in metamorphosis, in endocrine dependent tissue atrophy, and in the control of normal tissue turnover (Duvall \& Wyllie 1986). So it can be expected to find this amount of apoptotic cells in the cord blood since it still undergoes hematopoiesis.

In human umbilical cord blood, Mikami et al. (2001) observed lymphocytes in which the nucleus displays a cloverleaf like appearance, similar to those observed in Sezary syndrome, in adult T-cell leukemia (ATL) and in Sezary syndrome in dogs (Thrall et al. 1984, Ghernati et al. 1999). In this study lymphocytes with these same characteristics were also identified, nevertheless not associated to a leukemia sign.

The presence of cells at different stages of maturation and cells undergoing apoptosis exhibit high turnover undergone by the UCB cells.

\section{CONCLUSION}

The ultrastructural characteristics of bovine UCB cells observed in this study show to be very similar to those found in other species. This fact suggests the possibility of using this species as an experimental model for approaches on UCB cells ontogeny, culture and transplant, because of their high availability and abundance as source of cells.

Acknowledgments.- To Fundação de Amparo à Pesquisa do Estado de São Paulo for partially funding this research.

\section{REFERENCES}

Alsami M.T. \& Filippich L.J. 1999. Haematology of foetal sheep. Aust. Vet J 77(9):588-594.

Athens J.W. 1993a. Eosinophil - basophil, p.299-310. In: Lee R.G., Bithell T.C., Foerster J., Athens J.W. \& Lukens J.N. (Eds), Wintrobe's Clinical Hematology. $9^{\text {th }}$ ed. Lea and Febiger, Philadelphia.

Athens J.W. 1993b. Granulocyte - neutrophils, p.223-310. In: Lee R.G., Bithell T.C., Foerster J., Athens J.W. \& Lukens J.N. (Eds), Wintrobe's Clinical Hematology. $9^{\text {th }}$ ed. Lea and Febiger, Philadelphia.

Baggiolini M., Horisberger U., Gennaro R. \& Dewald B. 1985. Identification of three types of granules in neutrophil of ruminants. Lab. Invest. 52(2):151-158.

Capone J., Capone E.L.W. \& Chapman G.B. 1964. Electron microscope studies on normal human myeloid elements. Blood 23(3):300-320.

Carbonell F., Calvo W. \& Fliedner T.M. 1982. Cellular composition of 
human fetal bone marrow: Histologic study in methacrylate sections. Acta Anat. 113:371-375.

Cohen J.J. 1993. Apoptosis. Immunol. Today 14:123-130.

Deliliers L.G., Caneva L., Fumiatti R., Servida F., Rebulla P., Lecchi L., Harven E. \& Soligo D. 2001. Ultrastructural features of CD $34^{+}$ hematopoetic progenitor cells from bone marrow, peripheral blood and umbilical cord blood. Leukemia and Lymphoma 42(4):699708.

Duvall E. \& Wyllie A.H. 1986. Death and the cell. Immunol Today 7(4):115-119.

Ihara T., Yamamoto T., Sugmata M., Okumura H. \& Ueno Y. 1988. The process of ultrastructural changes from nuclei to apoptotic body. Virchows Arch. 433:433-447.

Gennaro R., Dewald B., Horisberger U., Gubler H.U. \& Baggiolini M. 1983. A novel type of cytoplasmic granule in bovine neutrophils. J. Cell Biol. 96:1651-1661.

Jain N.M. 1993a. The erythrocytes, p.247-257. In: Jain N.M. (Ed.), Essentials of Veterinary Hematology. Lea and Febiger, Philadelphia.

Jain N.M. 1993b. The neutrophils, p.222-246. In: Jain N.M. (Ed.), Essentials of Veterinary Hematology. Lea and Febiger, Philadelphia.

Ghernati C.A., Chabanne L., Corbin A., Bonnefont C., Magnol J.P.,
Fournel C., Rivoire A., Monier J.C. \& Rigal D. 1999. Characterization of a canine long-term $T$ cell line (DLC 01) established from a dog with Sezary syndrome and producing retroviral particles. Leukemia 13:1281-1290.

Ladgies W., Storb R. \& Thomas E.D. 1990. Canine models of bone marrow transplantation. Lab. Ann, Sci. 40:11.

Mikami T., Mitsuoki E., Hidemitsu K., Yuya S., Kenichi S., Hiroshi S., Nozomu T., Hiroshi W. \& Noriyuki I. 2002. Ultrastructural and cytochemical characterization of human cord blood cells. Med. Electron Microsc. 35:96-101.

Niemeyer G.P., Hudson J., Bridgman R., Spano J., Richard A.N. \& Lathrop C.D. 2001.

Isolation and characterization of canine hematopoetic progenitor cells. Exp. Hematol. 29:686-693.

Peters R., Leyvraz S. \& Perey L. 1998. Apoptotic regulation in primitive hematopoietic precursors. Blood 92:2041-2052.

Thrall M.A., Macy D.W., Snyder S.P. \& Hall R.L. 1984. Cutaneous lymphosarcoma and leukemia in a dog resembling Sézary syndrome in man. Vet. Pathol. 21:182-186.

Wynter E.A. \& Testa N.G. 2001. Interest of cord blood stem cells. Biomed. Pharmacother. 55:195-200. 